\title{
Pengolahan Palm Oil Mill Effluent (POME) menjadi Biogas dengan Sistem Anaerobik Tipe Fixed Bed tanpa Proses Netralisasi
}

\section{Palm Oil Mill Effluent (POME) Treatment into Biogas with Anaerobic System Type Fixed Bed without Neutralization Process}

\author{
WIDIATMINI SIH WINANTI, PRASETIYADI, WIHARJA \\ Pusat Teknologi Lingkungan, Badan Pengkajian dan Penerapan Teknologi \\ Gedung Geostech 820, Kawasan Puspiptek, Serpong, Tangerang Selatan, 15314 \\ Email: widiatmini.sih@bppt.go.id
}

\begin{abstract}
Palm Oil Mill wastewater or POME is currently not fully utilized. POME waste treatment generally uses covered lagoon technology using the anaerobic system, which generally operates well in neutral waste conditions with a pH of 7 and uses mesophilic processes at temperatures around $35^{\circ} \mathrm{C}$. So it is necessary to cool down and neutralize before POME is fed to the reactor, by mixing it with POME which has been degraded inside the reactor, where the $\mathrm{pH}$ condition has to turn into a base. It is useful to ensure that the POME temperature before being fed into the reactor is near the ambient temperature and the acidity of POME is near neutral $(\mathrm{pH}=7)$. POME treatment using a covered lagoon reactor usually need 30 days residence time. The Fixed Bed anaerobic reactor is capable to treat waste with a low $\mathrm{pH}$ waste, so POME which has a $\mathrm{pH}$ of 4 does not need to be neutralized before treating using Fixed Bed Reactor. This will simplify the processing process, reduce investment costs and operating costs. The purpose of this research is to process POME waste using an anaerobic type Fixed Bed reactor without neutralization stage. The method processing using Fixed Bed type reactor is divided into two stages of a process that is bacteria inoculation process and POME waste adaptation process. The results of the research can reduce the HRT to 20 days, with optimal POME feeding at 150 liters/day. The percentage of methane gas measured was $66 \%$. The methane gas yield is 0.52 liters/gram of COD or greater than the results of using the covered lagoon, which is 0.35 liters/ gram COD.
\end{abstract}

Key word: Palm Oil Mill Effluent (POME), anaerobic, Fixed Bed, biogas, neutralization

\section{ABSTRAK}

Limbah cair industri minyak kelapa sawit atau POME saat ini belum dimanfaatkan secara maksimal. Pengolahan limbah POME umumnya menggunakan teknologi covered lagoon dengan sistem anaerobik, dimana umumnya teknologi ini beroperasi baik pada kondisi limbah yang netral dengan $\mathrm{pH}$ 7 dan menggunakan proses mesopilik pada suhu sekitar $35^{\circ} \mathrm{C}$. Sehingga diperlukan tahap pendinginan dan tahap netralisasi terlebih dahulu sebelum POME diumpankan ke reaktor, yaitu dengan mencampurkannya dengan POME yang sudah terdegradasi di dalam reaktor, karena sifatnya sudah berubah menjadi basa. Hal ini berguna untuk memastikan bahwa suhu POME sebelum masuk reaktor sudah mendekati suhu lingkungan dan tingkat keasaman POME sudah mendekati netral $(\mathrm{pH}$ =7). Pengolahan POME menggunakan covered lagoon umumnya memerlukan waktu tinggal di dalam reaktor(HRT) sekitar 30 hari. Reaktor anaerobik tipe Fixed Bed mampu mengolah limbah dengan $\mathrm{pH}$ rendah, sehingga POME yang mempunyai $\mathrm{pH} \mathrm{4}$, tidak perlu dinetralkan terlebih dahulu. Hal ini akan menyederhanakan proses pengolahan, menurunkan biaya investasi dan biaya operasi. Tujuan penelitian ini adalah mengolah limbah POME dengan menggunakan reaktor anaerobik tipe Fixed Bed tanpa tahap proses netralisasi. Metode pengolahan anaerobik dengan menggunakan reaktor tipe Fixed Bed, terbagi menjadi dua tahapan proses yaitu proses inokulasi bakteri dan proses adaptasi limbah POME. Hasil penelitian dapat menurunkan HRT menjadi 20 hari, dengan pengumpanan POME optimal pada 150 liter/hari. Persentase gas metana adalah $66 \%$. Hasil produksi gas metana adalah 0,52 liter/gram COD atau lebih besar dari hasil proses menggunakan covered lagoon, yaitu 0,35 liter/ gram COD.

Kata Kunci: Palm Oil Mill Effluent (POME), anaerobik, Fixed Bed, biogas, netralisasi 


\section{PENDAHULUAN}

\subsection{Latar Belakang}

Laju perkembangan industri kelapa sawit di Indonesia saat ini semakin pesat karena Indonesia merupakan produsen minyak kelapa sawit terbesar di dunia. Luas areal perkebunan kelapa sawit di Indonesia pada tahun 2017 mencapai 12,3 juta hektar dengan produksi sebesar 35,36 juta ton minyak sawit ${ }^{(1)}$. Dalam prosesnya, industri kelapa sawit menghasilkan beberapa limbah jenis limbah dalam prosesnya, yang berupa limbah padat dan cair. Limbah cair industri kelapa sawit yang paling utama adalah Palm Oil Mill Effluent (POME).Setiap satu ton tandan buat segar kelapa sawit akan menghasilkan sekitar 0,7 - 0,8 $\mathrm{m}^{3}$ limbah POME. Limbah POME yang keluar dari proses pengolahan biasanya memiliki suhu tinggi yaitu berkisar antara 70$80^{\circ} \mathrm{C}$, dengan tingkat keasaman $(\mathrm{pH})$ sekitar 4,56 - 4,98, COD (Chemical Oxygen Demand) berkisar antara $57.000-60.400 \mathrm{mg} /$ liter dan Total Suspended Solid (TSS) 0,23 - 5,44 $\mathrm{g} / \mathrm{L}^{(2)}$. Alkyol tahun 2012 menyatakan bahwa tingginya angka COD dapat membahayakan ikan dan menngkontaminasi rantai makanan apabila dibuang langsung ke saluran pembuangan tanpa diolah terlebih dahulu. Oleh karena itu, pengolahan terbaik untuk buangan limbah yang memiliki kandungan organik yang tinggi adalah dengan cara pengolahan secara anaerobik.

Proses degradasi anaerobik merupakan proses fermentasi bahan organik oleh aktivitas bakteri anaerob pada kondisi tanpa oksigen bebas dan merubahnya dari bentuk tersuspensi menjadi terlarut dan biogas ${ }^{(3)}$. Proses anaerobik adalah salah satu teknologi yang paling hemat energi dan ramah lingkungan untuk produksi bioenergi(4). Pengolahan limbah secara anaerobik dapat diartikan sebagai proses biokimia yang menghasilkan biogas dengan merubah bahan organik kompleks menjadi sumber energi terbarukan ${ }^{(5)}$. Proses pengelohan anaerobik dapat memberikan keuntungan lebih dibandingkan pengolahan secara aerobik ${ }^{(7)}$, yaitu:

a. Proses anaerobik tidak membutuhkan energi untuk aerasi, sehingga mengurangi biaya pada proses pengolahannya

b. Lumpur atau sludge yang dihasilkan lebih sedikit dari proses aerobik.

c. Bahan pencemar berupa bahan organik yang dapat terbiodegradasi hampir semuanya dikonversi ke bentuk biogas (gas metana) yang mempunyai nilai kalor tinggi dan dapat digunakan sebagai subtitusi sumber energi.

Proses anaerobik dilakukan oleh konsorsium bakteri yang berinterelasi syntrophic sehingga dapat bakteri tersebut data saling memenuhi kebutuhannya masing-masing. Konsorsium bakteri yang terjadi pada proses pengolahan anaerobik diantaranya proses hidrolisis, proses asidogenesis, proses asetogenesis, dan proses metanogenesis. Tahapan proses pada pengolahan anaerobik tersebut saling terkait erat satu sama lain.. Secara garis besar ke empat tahap pada proses degradasi kimia secara anaerobik dapat dilihat pada Gambar 1 berikut ini( ${ }^{(8)}$.

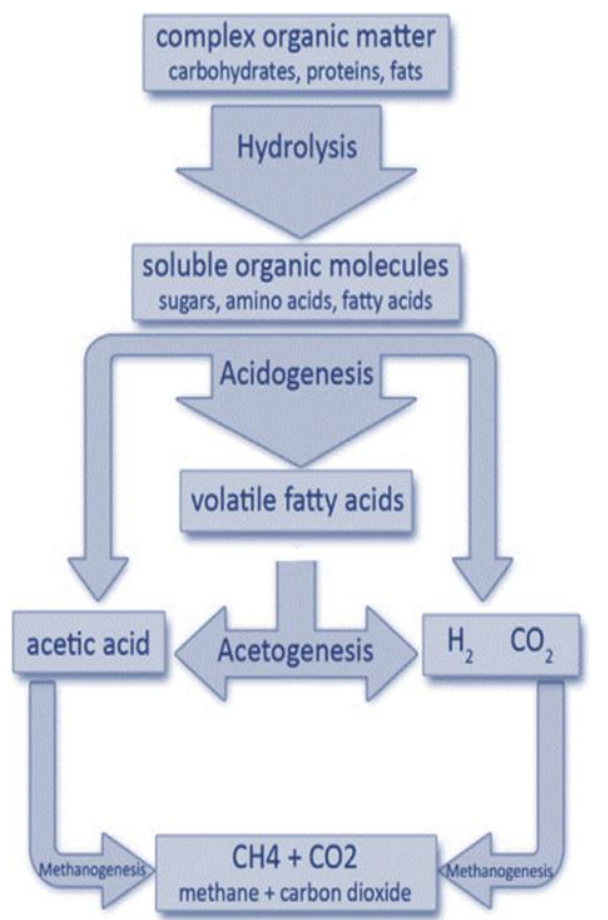

Gambar 1. Skema proses pengolahan anaerobik

Secara singkat Stronach et al, mengambarkan bahwa proses degradasi anaerobik dimulai dari biomasa, selulosa, hemi selulosa, karbohidrat, protein, dan lemak secara lambat di ubah bentuk menjadi glukosa, asam amino, gliserin, dan asam lemak oleh bakteri hidrolitik, selanjutnya hasil proses hidrolisis diubah dengan cepat oleh bakteri asidogenik menjadi $\mathrm{H}_{2} \mathrm{O}, \mathrm{NH}_{3}, \mathrm{H}_{2} \mathrm{~S}$, asam formiat, asam asetat, asam laktat, asam butirat, asam propionate, dan ethanol, selanjutnya secara lambat bakteri akan mengubah bentuk asetogenik asam butirat, asam propionate, dan ethanol menjadi $\mathrm{H}_{2}$, $\mathrm{CO}_{2}$, dan asam asetat, dan proses terakhir adalah perubahan bentuk $\mathrm{H}_{2}, \mathrm{CO}_{2}$, dan asam asetat oleh bakteri metanogenik yang berjalan dengan lambat menjadi biogas, $\mathrm{CH}_{4}$, dan $\mathrm{CO}_{2}$. 
Setiap bakteri dalam proses anaerobik memiliki kondisi proses yang berbeda. Stronach et al, menyatakan bahwa kondisi dan bakteri yang berperan selama proses anaerobik adalah sebagai berikut ${ }^{(9)}$ :

1. Bakteri hidrolitik memiliki kondisi proses fakultatif atau obligat anaerob dengan $\mathrm{pH}$ optimum 6,0-7,5. Bakteri hidrolitik diantaranya adalah Clostridium, Bacilus, Cellulomonas, Bacteriodes Ruminococcus

2. Bakteri asidogenik memiliki kondisi proses fukultatif atau obligat anaerob dengan $\mathrm{pH}$ optimum 6,0-7,5. Bakteri asidogenik diantaranya adalah Clostridium, lactobacilus, Selenomonas, Bacteriodes Ruminococcus

3. Bakteri asetogenik memiliki kondisi proses obligat anaerob dengan $\mathrm{pH}$ optimum 6,57,5. Bakteri asetogenik diantaranya adalah Desulfomonas,

Desulfotomaculum, Desulfovibrio

4. Bakteri metanogenik memiliki kondisi proses obligat anaerob dengan $\mathrm{pH}$ optimum 6,5-7,5. Bakteri metanogenik diantaranya adalah Methanobacterium, Methanococcus, Methanosarcine, Methanospirillum.

Jika kondisi proses ditangani dengan benar, maka proses pengolahan anerobik akan barjalan stabil hingga pemulihan energi tinggi(10). Namun, teknologi pengolahan anaerobik ini memiliki dua tantangan utama yaitu: (i) ketidakstabilan operasional dan (ii) kualitas pengolahan yang dihasilkan ${ }^{(11,12)}$. Hasil degradasi anaerobik komponen utama buangan limbah akan menghasilkan gas metan Pemilihan substrat organik memainkan peran penting dalam stabilitas sistem pengolahan anaerobik karena beberapa bahan baku dapat memiliki efek penghambatan pada proses pengolahan anaerobik ${ }^{(13)}$. Bentuk-bentuk penghambat pada proses anaerobik untuk substrat organik adalah yang mengandung sejumlah besar protein, lipid, limonene, furan, logam, pestisida, antibiotik dan senyawa organik lainnya ${ }^{(14 ; 15)}$.

Saat ini pengolahan limbah POME secara anaerobik masih menggunakan teknologi konvensional dengan menggunakan covered lagoon. Teknologi cover lagoon ini terdapat kekurangan yaitu memerlukan tahap pendinginan dan tahap netralisasi terlebih dahulu yaitu dengan penambahan larutan basa, yang biasanya dilakukan dengan mensirkulasi POME yang sudah terproses didalam reaktor, yang sudah mempunyai $\mathrm{pH}$ tinggi. Hal ini berguna untuk memastikan bahwa suhu POME sudah mendekati suhu lingkungan sekitar $30^{\circ} \mathrm{C}$ dan tingkat keasaman POME sudah mendekati netral $(\mathrm{pH}=7)$. Proses pendinginan dan proses netralisasi pada pengolahan limbah POME akan memerlukan waktu dan biaya yang lebih. Rata-rata waktu tinggal didalam cover lagoon adalah sekitar 30 hari.

Menurut Weiland, salah satu metoda terbaik untuk pengolahan limbah secara anaerobik dan dengan konsentrasi tinggi adalah teknologi Fixed Bed. Keunggulan proses kinerja reaktor tipe Fixed Bed adalah efisiensinya yang mencapai $75-85 \%{ }^{(16)}$. Reaktor tipe Fixed Bed adalah reaktor yang dilengkapi dengan material penyangga. Material penyangga berfungsi sebagai tempat menempel mikroba atau bakteri, sehingga mikroba tidak ikut terbawa cairan sisa buangan atau effluen yang keluar dari reaktor ${ }^{(17)}$. Berdasarkan hasil percobaan Cao et al., potongan bambu merupakan material penyangga yang cukup efektif sebagai tempat menempelnya bakteri. Bambu dapat menghasilkan biofilm yang tebal atau meningkatkan kepadatan pertumbuhan bakteri dalam reaktor, karena stuktur permukaan bambu yang berserabut dapat menghadang bahan organik termasuk bakteri ${ }^{(17)}$. Selain itu, material penyangga bambu juga tidak dapat ikut teruraikan dalam proses anaerobik serta potongan bambu dapat dimanfaatkan lebih dari 10 tahun $^{(18)}$. Bakteri-bakteri tersebut akan mendegradasi bahan-bahan organik yang terdapat pada limbah menjadi biogas yang bermanfaat.

\subsection{Tujuan Penelitian}

Tujuan dari penelitian ini adalah mengolah limbah POME dengan menggunakan reaktor anaerobik tipe Fixed Bed tanpa memerlukan tahap netralisasi.

\section{BAHAN DAN METODE}

\subsection{Tempat dan waktu penelitian}

Pengolahan limbah POME ini dilakukan dengan melalui uji coba skala bench scale di laboratorium Geostech, Perkantoran Puspiptek Serpong. Waktu penelitian ini dilakukan pada tahun 2017.

\subsection{Bahan dan Peralatan}

Bahan yang digunakan adalah Limbah cair POME yang didatangkan dari industri Pengolahan Kelapa Sawit di daerah Bogor. POME diambil langsung dari kolam tempat penampungan limbah. Pengambilan limbah dilakukan setiap minggu, supaya kondisi POME yang diolah adalah selalu segar dan diharapkan belum terjadi degradasi atau 
turunnya kandungan organik pada POME salama proses penyimpanan.

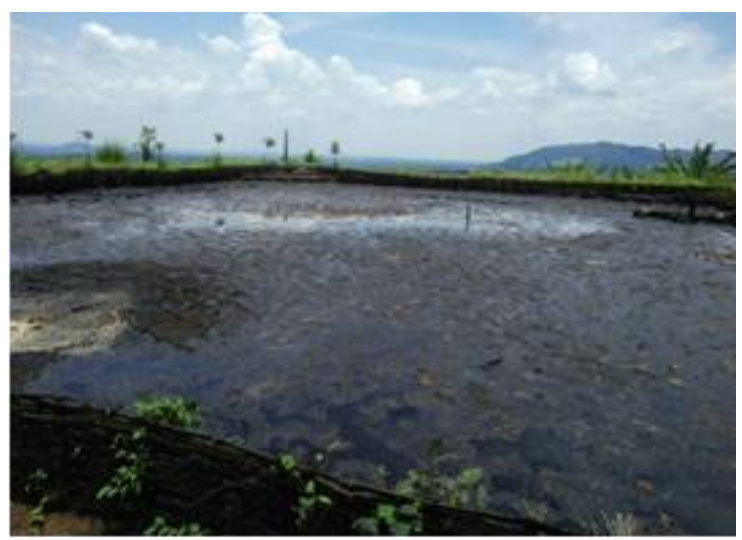

Gambar 2. Kolam POME

Limbah POME yang diambil dari kolam industri sawit dimasukkan ke dalam tangki tempat penampungan limbah

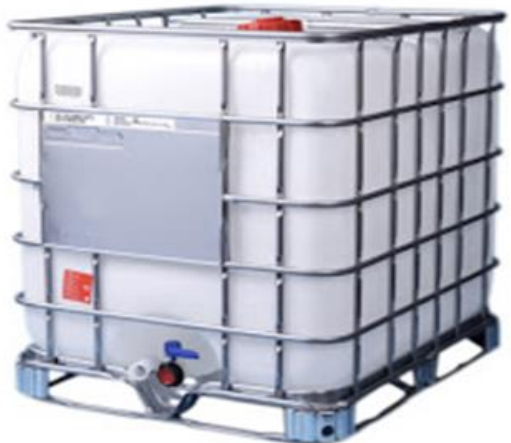

Gambar 3. Tangki penampung limbah

Peralatan yang digunakan adalah satu unit peralatan yang terdiri dari reaktor/digester anaerobic tipe Fixed Bed yang berbentuk tangki yang dilapisi dengan pelapis yang kedap udara, dan dilengkapi dengan peralatan pendukung. Rangkaian peralatan reaktor anaerobik tipe Fixed Bed dapat dilihat pada Gambar 4.

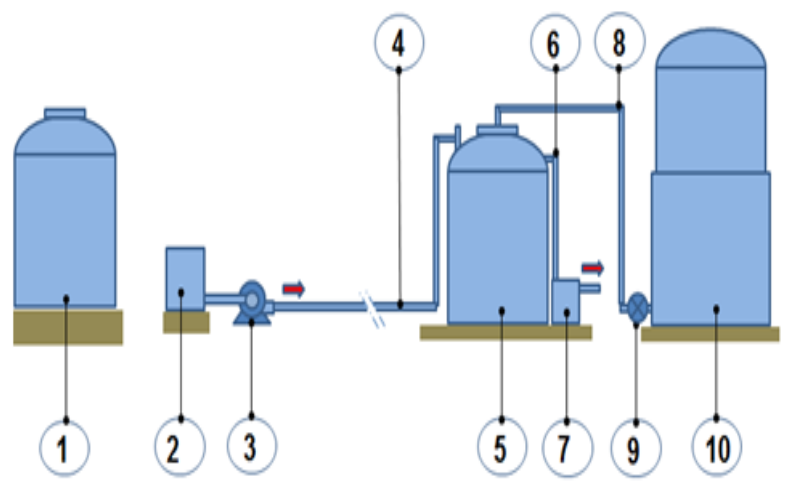

Gambar 4. Peralatan pengolahan pome dengan sistem Fixed Bed Reactor
Tabel 1. Keterangan gambar sistem Fixed Bed Reactor

\begin{tabular}{|c|c|c|c|}
\hline No & Nama & Jumlah & Kapasitas \\
\hline 1 & $\begin{array}{l}\text { Penampung } \\
\text { limbah }\end{array}$ & 3 buah & $1 \mathrm{~m} 3$ \\
\hline 2 & Tangki umpan & 2 buah & $1 \mathrm{~m} 3$ \\
\hline 3 & $\begin{array}{l}\text { Pompa umpan } \\
\text { \& sirkulasi }\end{array}$ & 2 buah & 30 liter/menit \\
\hline 4 & Pipa inlet & 1 paket & - \\
\hline 5 & Digester & 1 buah & $3 \mathrm{~m} 3$ \\
\hline 6 & $\begin{array}{l}\text { Pipa out let } \\
\text { effluence }\end{array}$ & 1 buah & \\
\hline 7 & $\begin{array}{l}\text { Bak penahan } \\
\text { gas }\end{array}$ & 1 buah & 150 liter \\
\hline 8 & Pipa biogas & 1 buah & \\
\hline 9 & $\begin{array}{l}\text { Flow meter } \\
\text { biogas }\end{array}$ & 1 buah & $\begin{array}{c}0,16-2,5 \\
\text { m3 per jam }\end{array}$ \\
\hline 10 & Gasholder & 1 buah & $3 \mathrm{~m} 3$ \\
\hline
\end{tabular}

Pada penelitian ini, material penyangga yang digunakan adalah bambu. Berdasarkan hasil percobaan Cao et al tahun 2012, potongan bambu merupakan material penyangga yang cukup efektif sebagai tempat menempelnya bakteri. Bambu dapat menghasilkan biofilm yang tebal atau meningkatkan kepadatan pertumbuhan bakteri dalam reaktor, karena stuktur permukaan bambu yang berserabut dapat menghadang bahan organik termasuk bakteri ${ }^{(17)}$ Bakteribakteri anaerobik yang menempel pada material penyangga akan mendegradasi kandungan bahan organik limbah cair tahu menjadi biogas.

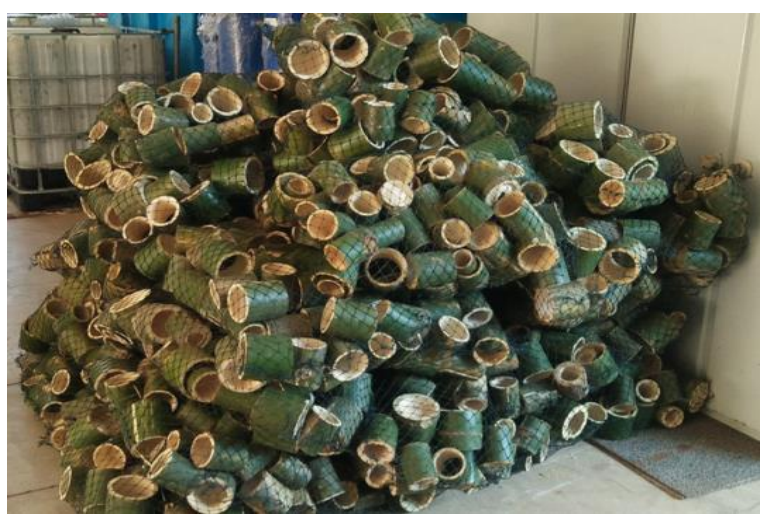

Gambar 5. Potongan Bambu sebagi support material

\subsection{Metode}

Proses pengolahan limbah secara anaerobik ini terbagi menjadi 2 tahap yaitu tahap inokulasi dan tahap adaptasi limbah POME.

\section{Tahap Inokulasi}

Inokulasi adalah pemindahan suatu mikroorganisme ke dalam mikroorganisme lain 
atau ke dalam suatu substrat. Pada tahap inokulasi ini digunakan kotoran sapi yang telah disaring dan ditambahkan dengan air. Kotoran sapi dipilih karena mengandung poli bakteria dan terdapat didalamnya bakteri pembentuk metan. Cairan kotoran sapi dibuat ini dengan mengencerkan kotoran padat sapi dan air dengan perbandingan 1:1. Campuran air ini di maksudkan untuk mempermudah kotoran sapi untuk dapat dipompakan dan masuk kedalam digester. Cairan kotoran sapi tersebut selanjutnya diisi sesuai dengan volume kerja reaktor. Kemudian dilakukan inkubasi hingga terlihat adanya gas yang terbentuk yang mengindikasikan adanya bahan organik di kotoran sapi yang terdegradasi. Tahap ini ini harus diciptakan kondisi yang cukup baik agar mikroorganisme dapat tumbuh yang ditandai dengan terbentuknya lapisan tipis biofilm pada permukaan material penyangga. Proses biodegradasi secara anaerobik yang melibatkan bakteri-bakteri inokulum dapat mempengaruhi beberapa parameter diantaranya $\mathrm{pH}$, terbentuknya biogas, dan gas metana. Bila proses inkubasi kotoran sapi atau inokulasi telah berjalan dengan dengan baik, maka akan dilanjutkan dengan proses adaptasi pemberian POME.

\section{Tahap Adaptasi Limbah POME}

Setelah proses inokulasi berjalan dengan baik, kemudian reaktor tersebut diadaptasikan secara anaerobik dengan POME yang dilakukan secara kontinu dimulai dari beban organik dalam jumlah rendah hingga beban organik dengan jumlah yang tinggi. Proses adaptasi POME ini dilakukan pada suhu mesofilik atau pada kondisi ruang. Sistem aliran pada reaktor ini adalah menggunakan tipe aliran up flow. sistem up flow adalah substrat umpan masuk melalui dasar reaktor yang kemudian terdistribusi diantara material penyangga dan keluar pada bagian atas. Akumulasi bakteri yang terjadi di material penyangga, dapat mempermudah bakteri utuk menempel pada permukaan material penyangga. Pada setiap kenaikan laju beban akan dilakukan pengamatan lapangan harian untuk mengamati kestabilan reaktor diantaranya; $\mathrm{pH}$, produksi biogas yang dihasilkan dan \% kandungan metan. Kondisi dikatakan stabil apabila jika dilakukan pengisian umpan, produksi gas akan bertambah, namun $\mathrm{pH}$ dan \% metan tidak turun. Apabila salah satu indikator ini menunjukkan penurunan, hal ini menandakan proses didalam digester sudah terganggu dan dan apabila dua dari tiga indikator ini mengalami penurunan maka jumlah pengisian harus dikurangi atau dihentikan.

\section{HASIL DAN PEMBAHASAN}

Desain peralatan penelitian yang dibuat pada penelitian ini adalah reaktor anaerobik tipe Fixed Bed dengan menggunakan bahan berupa fiberglas berbentuk silinder dengan volume total $3,5 \mathrm{~m}^{3}$, dengan ukuran diameter dan tinggi adalah 1:1. Bahan fiberglas dipilih karena selain kuat terhadap guncangan, bahan fiberglas juga dapat tahan terhadap asamnya limbah POME sehingga reaktor tidak mudah korosif. Di dalam digester pengolahan limbah POME dengan menggunakan reaktor anaerobik tipe Fixed Bed ini terdapat support material. Support material yang digunakan adalah potongan bambu dengan ukuran 5-7 $\mathrm{cm}$. pemotongan bambu dilakukan agar dapat memperluas permukaan tempat tumbuhnya bakteri. Pemilihan bambu sebagai support material juga didasari dengan ketersediaan bahan tersebut mudah didapat dan harganya yang relatif murah.

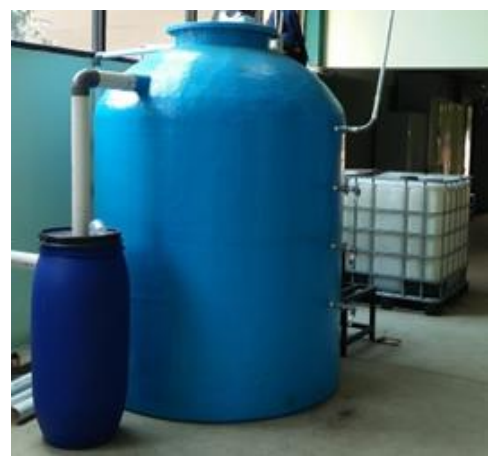

Gambar 6. Fixed Bed Reactor

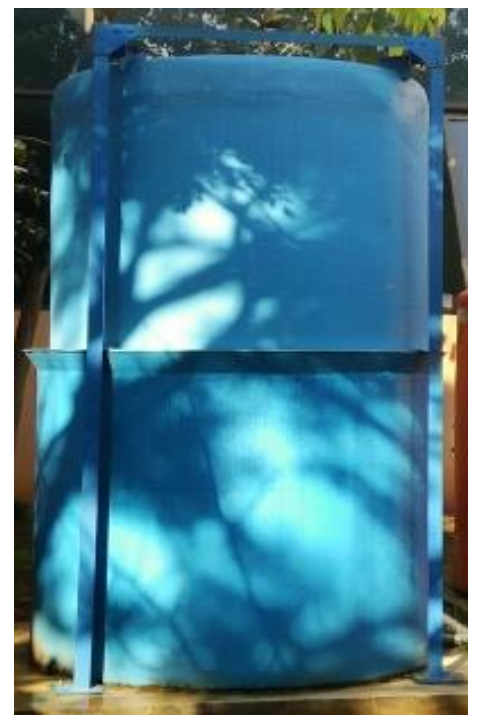

Gambar 7. Gas holder tipe floating

Walaupun support material ini dapat berfungsi sebagai tempat berkembangbiaknya bakteri, namun support material ini juga menempati volume ruang yang berada di dalam reaktor. Oleh karena itu hasil 
pengukuran didapat bahwa persen porositas bambu adalah $89,6 \%$ atau dengan kata lain bambu dapat menempati volume ruang reaktor sebanyak $10,4 \%$ sehingga volume efektif reaktor menjadi $3 \mathrm{~m}^{3}$. Volume efektif reaktor akan berpengaruh terhadap perhitungan waktu tinggal POME di dalam reaktor. Biogas yang dihasilkan dari reaktor, ditampung dalam gas holder. Gas holder yang digunakan adalah tipe floating, yang terdiri dari beberapa bagian yaitu tangki bagian bawah, tangki atas, tiang, rol dan saluran gas.

Tahap start up dilakukan menggunakan starter kotoran sapi Setelah kondisi stabil. dimulai pengumpanan menggunakan limbah POME secara bertahap, sampai sekitar 100 hari. Hasil seluruh pengamatan harian yang dilakukan selama tahap adaptasi dapat dilihat pada Gambar 8 dibawah ini.

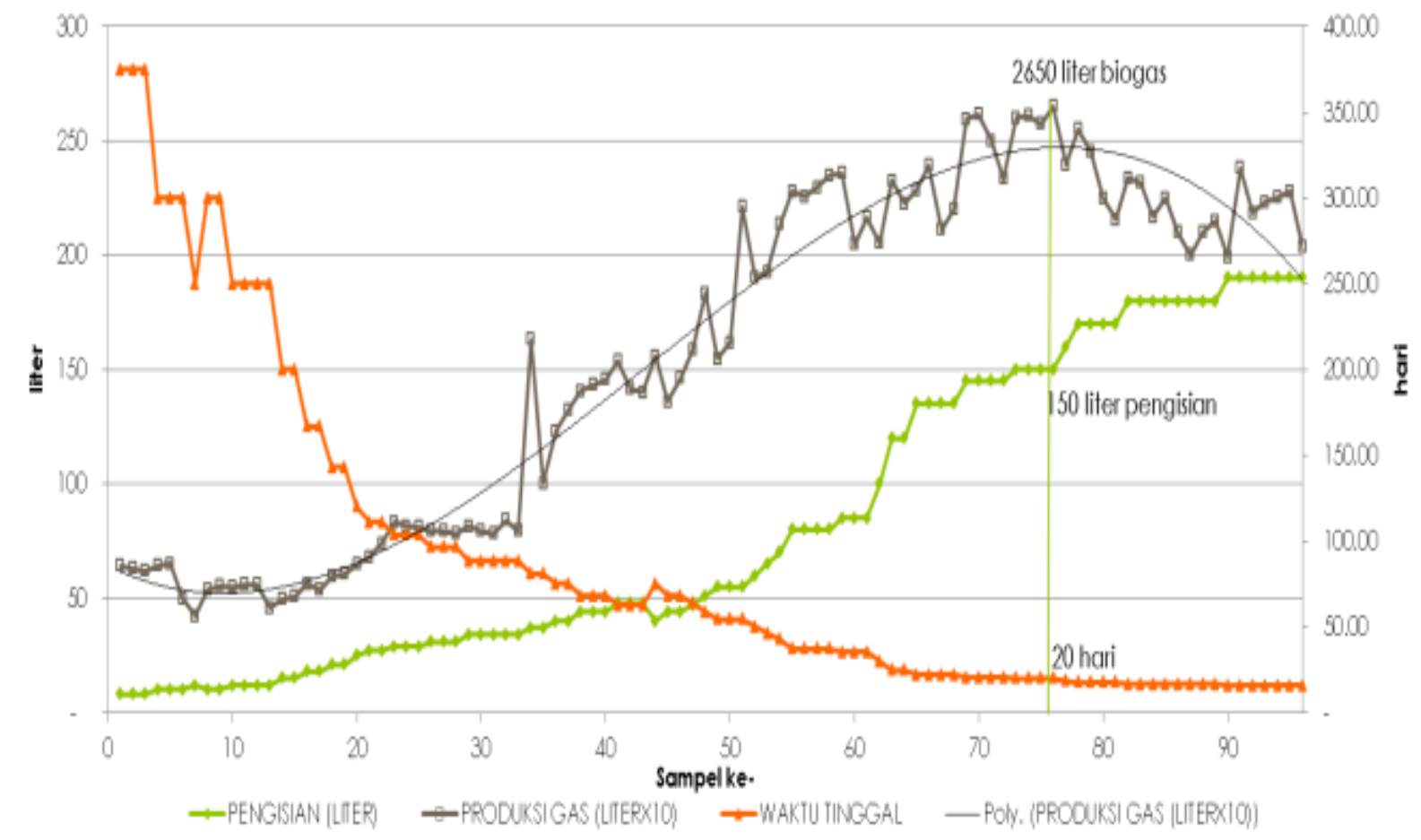

Gambar 8. Pengamatan harian produksi biogas, volume pengsian POME perhari (laju beban), dan waktu tingggal selama tahap operasi

Hasil pengamatan harian pada Gambar 8, menunjukkan bahwa pada sampel ke 91 adalah titik optimum dengan kondisi pemasukan umpan POME sebanyak 150 liter perhari. Berdasarkan hasil pengamatan titik optimum pemasukan umpan, maka dapat dihitung waktu tinggal substrat di dalam reaktor. Waktu tinggal didapat melalui perhitungan dari pembagian antara volume kerja atau volume efektif reaktor dengan jumlah pengisian umpan masuk limbah POME kedalam reaktor. Waktu tinggal optimum POME didalam reaktor yang dihasilkan pada sampel ke 91 adalah sebesar 20 hari.

Pengamatan harian yang juga dilakukan adalah produksi biogas yang merupakan hasil dari proses degradasi limbah cair organik secara anaerobik menjadi senyawa sederhana berbentuk gas. Pembentukan biogas tersebut sangat bergantung pada komposisi kimia substrat atau COD yang didegradasi.
Degradasi $1 \mathrm{~g}$ COD menghasilkan 0,35 liter gas metana ${ }^{(19)}$. Jumlah produksi biogas optimum yang terukur pada alat flowmeter pada sampel ke 91 adalah 2.650 liter biogas perhari, sedangkan persentase gas metana dalam biogas yang terukur pada sampel ke 91 dengan alat GA5000 adalah 66\%.

Pengukuran beban COD pada sampel ke 91 didapat sebesar 17.783,25 $\mathrm{mg} /$ liter. Berdasarkan beban COD tersebut dapat dihitung volume gas metana yang terbentuk. Berdasarkan data-data pengukuran pada sampel ke 91 tersebut dapat terlihat bahwa 1 g COD dapat menghasilkan 0,52 liter gas metana. Hal ini menunjukkan bahwa gas metan yang dihasilkan lebih besar dari standar teori gas metan yang dapat terdegradasi yaitu 0,35 liter $^{(19)}$. Hal ini dapat disebabkan kemungkinan karena terdegradasinya padatan yang terikut. Pada hari berikutnya, ketika beban umpan POME dinaikkan kembali, maka 
terjadi penurunan degradasi, dimana $1 \mathrm{~g}$ COD rata-rata hanya mampu menghasilkan 0,15 liter gas metana. Hal tersebut menandakan bahwa reaktor tersebut hanya mampu menerima beban optimum 17.783,25 mg/liter. Dengan kata lain jika pembebanan terus ditingkatkan maka produksi biogas yang dihasilkan sudah tidak optimal.

Oleh karena itu berdasarkan pengamatan harian sesuai dengan Gambar 8, maka dapat disimpulkan titik optimum dicapai pada hari ke 91 ketika:

1. Pemasukan umpan POME sebanyak 150 liter

2. Waktu tinggal POME didalam reaktor adalah 20 hari; lebih cepat dibandingkan menggunakan Covered lagoon yang 30 hai

3. Biogas maksimum mencapai 2.650 liter perhari

4. Persentase gas metana yang terukur adalah $66 \%$, dan

5. Kemampuan dengradasi kandungan organik mencapai 0,52 liter gas metan/ gram COD, yang lebih besar dibandingkan dengan proses yang umum dilakukan yaitu 0,35 liter gas metan/ gram COD.

\section{KESIMPULAN}

Rata-rata kandungan gas metan yang dihasilkan adalah $64 \%$. Produksi tebaik diperoleh pada sampel ke 91 , dengan input POME150 liter, dan HRT 20 hari. Persentase gas metan yang terukur pada sampel ke 91 adalah $66 \%$. Hasil gas metan pada sampel ke 91 adalah 0,52 liter/gram COD (lebih besar dari standar 0,35 liter yang disebabkan kemungkinan karena terdegradasinya padatan yang terikut).

\section{PERSANTUNAN}

Ucapan terima kasih diucapkan kepada Pusat Teknologi Lingkungan yang telah mendukung kegiatan penelitian ini.

\section{DAFTAR PUSTAKA}

1. Statistik Perkebunan Indonesia 20152017 Kelapa Sawit, Direktorat Jenderal Perkebunan, Kementerian Pertanian. (2018).

2. Shintawati, Hasanudin, U., Haryanto, A. (2017). Karakteristik Pengolahan Limbah Cair Minyak Kelapa Sawit dalam Bioreaktor Cigar Kontinu. Jurnal Teknik Pertanian Lampung, Vol. 6, No. 2, 81-88
3. Siddharth, S. (2006). Green Energy Anaerobic Digestion. Proceedings of The 4th WSEAS Int. Conf. On Heat Transfer, Thermal Engineering And Environment, Elounda, Greece, August 21-23, Third Year Chemical Engineering. Sri Venkateswara College Of Engineering Sriperumbudur Anna University. Pp 276280.

4. Fehrenbach $\mathrm{H}$, Giegrich J, Reinhardt G, Sayer U, Gretz M, Lanje K,Schmitz J. (2008) Kriterien einer nachhaltigen Bioenergienutzungim globalen Maßstab UBA-Forschungsbericht 206:41-112

5. Hagos, K., Zong, J., \& Liu, D. L. C. (2016). Anaerobic co-digestion process for biogas production: Progress, challenges and perspectives. State Key Laboratory of Materials-Oriented Chemical Engineering, Nanjing Tech University, Nanjing 210009

6. Nawawi, Hadari, (1995). Instrumen Penelitian Bidang Sosial. Yogyakarta: Gadjah Mada University Press

7. Nurhadi. (2010). Evaluasi Kinerja Reaktor Upflow Anaerobic Sludge Blanket (ASB) dan Downflow Hanging Sponge (DHS) dalam Mengolah Air Limbah Domestik: Kajian Terhadap Kualitas Air Waduk Setiabudi Jakarta Selatan. Tesis. Universitas Indonesia

8. Amaya, O.M., Barragán, M.T.C., Tapia, F.J.A. (2013). Microbial Biomass in Batch and Continuous System.

9. Stronach, S. M., Ruud, T., Lester J. N. (1986). Anaerobic Digestion Processess in Industrial Waste Water Treatment, Biotechnology Monographs, Springer Verlag, Berlin, Heidelberg.

10. Dechrugsa, S., Kantachote, D., Chaiprapat, S., (2013). Effects of inoculum to substrate ratio, substrate mix ratio and inoculum source on batch co-digestion of grass and pig manure. Bioresour. Technol. 146, 101-108.

11. Holm-Nielsen, J.B., Al Seadi, T., Oleskowicz-Popiel, P., 2009. The future of anaerobic digestion and biogas utilization. Bioresour. Technol. 100 (22), 5478-5484.

12. Appels, L., Lauwers, J., Degrève, J., Helsen, L., Lievens, B., Willems, K., Van Impe, J., Dewil, R., 2011. Anaerobic digestion in global bio-energy production: potential and research 
challenges. Renew. Sustain. Energy Rev. 15 (9), 4295-4301

13. Fagbohungbe, Michael O., Herbert, Ben M.J., Hurst, Lois., Ibeto, Cynthia N., Li, Hong., Usmani, Shams Q., Semple, Kirk T. (2017). The challenges of anaerobic digestion and the role of biochar in optimizing anaerobic digestion. Waste Management 61 (2017) 236-249

14. Sousa, D.Z., Salvador, A.F., Ramos, J., Guedes, A.P., Barbosa, S., Stams, A.J.M., Alves, M. M., Pereira, M.A., (2013). Activity and viability of methanogens in anaerobic digestion of unsaturated and saturated long-chain Fatty acids. Appl. Environ. Microbiol. 79 (14), 4239-4245.

15. Yangin-Gomec, C., Ozturk, I., 2013. Effect of maize silage addition on biomethane recovery from mesophilic co-digestion of chicken and cattle manure to suppress ammonia inhibition. Energy Convers. Manage. 71, 92-100

16. Weiland, P. (1987). Development of anerobic filters for treatment of high strength agro industrial waste water. Bio Process Engineering, 2, 39 - 47, Springer - verlag

17. Cao, Wenping., Zhang, Houhu., Wang, Yinmei., Pan, JiZheng. (2012). Bioremediation of Polluted surface water by using biofilms on filamentous bamboo. Ecological engineering 42. 146149

18. Feng, Huajun., Hu, Lifang., Mahmood, Qaisar, Quu, Caidi., Fang, Chengran., Shen, Dongsheng. (2008). Anaerobic domestic wastewater teratment with bamboo carrier anaerobic baffled reactor. International Biodeterioration and Biodegradation 62 (18 June 2008) 232-238.

17. Castrillon, P., Fernandez-Nava, Y., Ormaechea, \& Maranon, E. (2013). Methane production from cattle manure supplemented with crude glycerin from the biodiesel industry in CSTR and IBR. Austria. Bioresource Technology 127. 312317. 